\title{
The Impact of Equity Mix and Executive Incentives on Corporate Performance
}

\author{
Jing Li \\ School of Economics and Management, Shanghai Maritime University, Shanghai, China \\ Email: 15955163619@163.com
}

How to cite this paper: Li, J. (2021). The Impact of Equity Mix and Executive Incentives on Corporate Performance. Open Journal of Business and Management, 9, 1409-1423.

https://doi.org/10.4236/ojbm.2021.93075

Received: April 7, 2021

Accepted: May 28, 2021

Published: May 31, 2021

Copyright (อ 2021 by author(s) and Scientific Research Publishing Inc. This work is licensed under the Creative Commons Attribution International License (CC BY 4.0).

http://creativecommons.org/licenses/by/4.0/

\begin{abstract}
On the background of mixed ownership reform, the equity mix has an increasing impact on corporate performance. Our research selects the panel data of 620 Shanghai and Shenzhen A-share manufacturing listed companies from 2015 to 2019, and constructs a model of the mediating effect of "equity mix-executive incentives-corporate performance" to test the impact of equity mix on firm performance, and further explore the mediating effect of executive incentives between the equity mix and firm performance. Research shows that: the " $U$ "-shaped relationship between equity mix and company performance is confirmed, executive compensation incentives have a partial mediating effect between equity mix and firm performance, and executive equity incentives have a complete mediating effect between equity mix and company performance.
\end{abstract}

\section{Keywords}

Equity Mix, Executive Incentives, Corporate Performance

\section{Introduction}

Over recent years, "mixed ownership reform" has always been a topic with state-owned listed companies. Since 2015, the State Council of the People's Republic of China issued several documents, and the general requirements, core concept and necessary measures for state-owned companies to develop mixed-ownership economy have been clarified. In 2016, the State Council of the People's Republic of China issued several documents on management of executives in state-owned enterprises, which promoted the diversification of the remuneration system and incentive system for the management of state-owned enterprises. In 2020, state-owned enterprise reform has entered a critical stage. In this context, the impact of equity mix and executive incentives on business 
performance has attracted more and more attention in the academic research.

"Mixed ownership reform" is a reform plan put forward in the 1990s, which aims to introduce private capital to promote the development of productivity. The essence of mixed ownership reform is to introduce diversified investment entities through capital increase and share expansion, so as to make capital heterogeneous and diversified, thereby optimizing the ownership structure, establishing a good governance mechanism, and comprehensively enhancing the competitiveness of enterprises. "Mixed ownership reform" is a reform of the property rights system. This reform has caused changes in the company's equity system and equity structure. The ownership and control of modern enterprises are separated. Managers may make decisions that are detrimental to shareholders' rights and interests to make their benefits maximization. Executive incentives align the interests of management and shareholders by granting managers a certain salary or equity. It can effectively alleviate the principal-agent problem, thereby improving the efficiency of corporate governance. So, can the changes in the equity structure triggered by the "mixed ownership reform" improve corporate performance? What proportion of equity mix must be achieved to achieve the effect of performance improvement? Are executive incentives a intermediary role in equity mix and company performance? At present, in the study of equity mix and business performance, research on the relationship among equity mix, executive incentives and company performance under the background of the "mixed ownership reform" has not been involved. To a certain extent, this paper can provide some suggestions for the corporate governance of mixed ownership enterprises, so as to promote the improvement of enterprise performance.

\section{Literature Review and Theoretical Analysis}

\subsection{The Relationship between Equity Mix and Company Performance}

On the one hand, the degree of equity mixing measures the proportion of non-state-owned stock in state-owned companies, and represents the proportion of non-state-owned shareholders' holdings after "mixed ownership reform"; on the other hand, it also measures the degree of checks and balances between non-state-owned stock and state-controlled stock, which is a restrict-balance mechanism between non-state-owned stockholders and state-owned stockholders. Pagano and Roell (1998) conducted a research on the issue of shareholding structure, and believes that the supervision cost of other types of shareholders under the decentralized shareholding structure was greatly reduced, which could form a restrict-balance mechanism for heavy stockholders, thereby improving corporate performance. Megginson and Netter (2001) found that reducing the proportion of state-owned stock of state-owned companies can promote profitability and operating efficiency of companies. Qian and Liu (2019) found that mixed ownership companies have higher performance, and there is a significant positive correlation between equity mix and business performance. 


\subsection{The Relationship between Executive Incentives and Corporate Performance}

There exists a separation of ownership and control in modern enterprises. Due to information asymmetry, the management may neglect the long-term development of firms in order to make their own benefits maximization. To solve the agency problem, scholars have done research about the impact of executive incentives on corporate performance. Hall and Liebman (1998) found that management compensation incentive is positively correlated with business performance. Cheng and Xia (2008) found that the implementation of equity incentives for management can improve corporate performance. Xi (2012) divides management incentives into management compensation incentives and equity incentives, and the research shows that two incentive methods can significantly enhance corporate value.

\subsection{The Mediating Effect of Executive Incentives}

Due to the separation of ownership and control, the management may act for their own interests, which will damage the interests of shareholders. Through compensation incentives and equity incentives, the management can effectively alleviate the agency problem, and make the personal interests of managers consistent with the long-term interests of the enterprise, thus promoting the improvement of enterprise performance. Yermack (1995) found that after the implementation of mixed ownership reform, enterprises tend to give certain equity incentive to the management in order to alleviate the problem of insufficient liquidity, thereby improving efficiency of corporate governance. Zou et al. (2015) found that in the state-owned companies, strengthening the equity check and balance helps to restrain the effect of equity incentive on the increase of the cost of equity capital, so as to significantly improve the effect of management equity incentive.

Based on the previous literature about the impact of equity mix on corporate performance and the impact of executive incentives on corporate performance, this paper finds: 1) Most studies on equity mix degree and corporate performance show that corporate performance will improve with the increase in equity mix, and the transmission mechanism and indirect effects between equity mix and corporate performance have not yet been paid attention to; 2) There are few studies about the impact of executive incentives on firm performance based on the background of "mixed ownership reform"; 3) There is no academic research on the comprehensive relationship among equity mix, executive incentives and corporate performance. Therefore, based on the background of "mixed ownership reform", the comprehensive relationship among the equity mix, executive incentives and company performance needs to be further studied.

\subsection{The Theoretical Analysis}

\subsubsection{Hypothesis One}

The shareholders of mixed ownership enterprises are split into state-owned 
stockholders and non-state-owned stockholders. The equity mixing degree is the degree of mixing of state-owned and non-state-owned capital in mixed ownership enterprises. Mixed ownership firms have different property rights. For one thing, this kind of checks and balances between heterogeneous shareholders will have a supervisory effect on state-owned controlling shareholders. It can intervene in the decision-making of state-owned shareholders, thereby improving corporate governance, and making business decisions more conducive to the firm's long-term business; for another, the increase in equity mixing degree is conducive to making scientific group decisions, reducing the irrational behavior of the management, and improving the performance of the enterprise. Mixed ownership enterprises are composed of equity with different ownership properties, and the existence of heterogeneous shareholders will have a check and balance and supervision effect on controlling shareholders. If the degree of mixing is very low, it means that the company is fully controlled by state-owned shareholders, and non-controlling shareholders have very low discursive power. The supervisory role will be weakened, and the company is more likely to make decisions that serve the interests of state-owned stockholders, which is not conducive to business decision-making. But this phenomenon will be eased as the degree of equity mix increases. Therefore, raising the proportion of non-state-owned shares in the "mixed ownership reform", so that equity mixing degree reaches a certain proportion, can improve corporate performance.

H1: The equity mixing degree and company performance present a " $U$ "-shaped relationship.

\subsubsection{Hypothesis Two}

Based on principal-agent theory, the separation of operation and ownership in enterprises will lead to a principal-agent problem. In a "mixed ownership reform" enterprise, heterogeneous shareholders can play an important role in supervision and checks and balances on state-owned stockholders. To alleviate agency problem, heterogeneous shareholders will improve the level of executive incentives, and reduce the self-interest of managers through long-term equity incentives and short-term compensation incentives, thereby reducing corporate agency costs. Huo et al. (2019) believe that the mixed ownership reform should be actively paid attention to so as to promote executive incentives. The low degree of equity mixing only introduces non-state-owned shares in form, but state-owned shareholders still control decision-making power, and will not have a positive impact on changes in executive compensation. However, with the increase in the degree of equity mixing, when the degree of mix of state-owned stock and non-state-owned stock reaches a certain ratio, non-state-owned stockholders can take part in the decision-making and achieve the purpose of supervision, so that it can improve the executive compensation incentives and the level of executive shareholding.

H2a: There is a " $U$ "-shaped relationship between equity mixing degree and 
executive compensation incentives.

$\mathrm{H} 2 \mathrm{~b}$ : There is a " $U$ "-shaped relationship between equity mixing degree and executive equity incentives.

\subsubsection{Hypothesis Three}

Due to information asymmetry, the management's behavior is difficult to be constrained, and managers may be for self-interest and damage the interests of shareholders. According to the motivation theory, effective salary incentives and equity incentives can meet the needs of executives to a greater extent, guide executives' decision-making behavior, effectively alleviate agency problems, and align the personal interests of managers with the long-term interests of the company, thereby promoting corporate performance. Executive incentives can promote the convergence of the goals of owners and operators, mobilize the managers' enthusiasm for work, reduce agency costs, and finally improve corporate performance. Then, how the degree of equity mix affects corporate performance, during which there may be a mediating transmission effect. According to principal-agent theory and motivation theory, how to effectively alleviate agency problems and reduce agency costs is the purpose of corporate governance research, enabling managers to make decisions based on the interests of stockholders and ultimately improve corporate performance. Bennedsen \& Wolfenzon (2000) found that the improving the level of equity balances can effectively supervise the behaviour of the management, suppress opportunistic behavior, and improve the effectiveness of management equity incentives. Cai et al. (2018) found that the participation of non-state shareholders in corporate governance can significantly increase the sensitivity of executive compensation and effectively alleviate the agency problems such as excessive compensation of executives, thereby effectively improving the incentive effect of the company. As an important part of the corporate governance mechanism, the degree of equity mix can also indirectly improve corporate performance by increasing the level of executive incentives. Therefore, executive compensation incentives and equity incentives may have a kind of effect between equity mix and corporate performance.

$\mathrm{H} 3 \mathrm{a}$ : Executive compensation incentives have a mediating effect between equity mixing degree and firm performance.

$\mathrm{H} 3 \mathrm{~b}$ : Executive equity incentives have a mediating effect between equity mixing degree and firm performance.

\section{Model Design}

\subsection{Sample Selection and Data Sources}

We choose manufacturing listed companies on the Shanghai and Shenzhen Stock Exchange from 2015 to 2019. In order to avoid biased empirical results under the influence of special data, the following treatments were made on the data: 1) We removed samples of listed companies with ST and ${ }^{\star}$ ST; 2) We ex- 
cluded listed companies with missing data; 3) The extreme values of some key indicators are tailed off. After the above screening, this paper finally collected 3100 effective sample data of 620 listed companies. At the same time, this paper performs winsorize processing on the main continuous variables at the $1 \%$ level. Table 1 shows the specific data sources of variables.

\subsection{Variable Definitions}

\subsubsection{Explained Variable}

Regarding the corporate performance, the indicators for measuring company performance are mainly divided into market indicators and financial indicators. This paper selects the return on total assets (ROA) as the measurement indicator. Since China's stock market is imperfect at present, the market value of public companies cannot well represent the company's future cash flow, and the Tobin's $\mathrm{Q}$ of the market indicator does not represent the company's performance level. Therefore, we choose the financial indicator "ROA" to judge corporate performance.

\subsubsection{Explanatory Variables}

Regarding the degree of equity mix (OMD), we prefer the quantitative methods of Yang et al. (2016), and use the ratio of the proportion of state-owned shares of the top 10 majority stockholders to the proportion of non-state-owned shares, with the smaller of the two as the numerator and the larger as the denominator. The value range of equity mix is from 0 to 1 . The closer that this value is to 1 , the higher the mixing degree.

\subsubsection{Mediator Variable}

Executive incentive is a mediator variable, which mainly includes long-term equity incentives and short-term compensation incentives. Executive Equity Incentives (MSH) is measured by the natural logarithm of management's shareholding.

Table 1. Data sources.

\begin{tabular}{cl}
\hline Variable name & Data Sources \\
\hline ROA & CSMAR Database \\
OMD & CSMAR Database \\
MSW & CSMAR Database \\
MSH & CSMAR Database \\
Size & CSMAR Database \\
Lev & CSMAR Database \\
Grow & CSMAR Database \\
Ocfps & CSMAR Database \\
AT & CSMAR Database \\
Board & CSMAR Database \\
\hline
\end{tabular}


Executive Salary Incentives (MSW) is measured by the natural logarithm of top three executive salaries. Table 2 shows the definition of variables.

\subsection{Research Model Design}

There may be a mediating effect in the process of equity mix affecting corporate performance. Equity mix is an important corporate governance mechanism (Yermack, 1995), which can indirectly improve corporate performance by improving the level of executive incentive. Therefore, executive incentives may have a conduction effect in the process of the impact of equity mix on corporate performance.

We study the comprehensive relationship among equity mix, executive incentives and corporate performance. First, to verify the "U"-shaped relationship between equity mix and corporate performance, this paper constructs a multiple regression model as follows:

$$
\mathrm{ROA}=\beta_{0}+\beta_{1} \mathrm{OMD}+\beta_{2} \mathrm{OMD} 2+\beta_{3} \text { Controls }+\varepsilon
$$

Second, we study the relationship among equity mix, executive incentives and corporate performance. Du et al. (2012) found that the full-effects adjustment model of Edwards and Lambert is more effective than the basic mediation model of Baron and Kenny when studying the nonlinear mediator variables. Therefore, based on the full effect adjustment model, this paper verifies the relation among equity mix, executive incentives and firm performance, and construct the following model:

$$
W=\alpha_{0}+\alpha_{1} X+\alpha_{2} Z+\alpha_{3} X Z+\alpha_{4} \text { Controls }+\varepsilon
$$

\begin{tabular}{|c|c|c|}
\hline Variable type & Variable name & Variable definitions \\
\hline Explained variable & ROA & Net income/Average total assets \\
\hline $\begin{array}{l}\text { Explanatory } \\
\text { variable }\end{array}$ & OMD & $\begin{array}{c}\text { If state-owned shares }>\text { non-state-owned shares, OMD }= \\
\text { non-state-owned shares/state-owned shares; If state-owned } \\
\text { shares }<\text { non-state-owned shares, OMD = state-owned } \\
\text { shares } / \text { non-state-owned shares }\end{array}$ \\
\hline \multirow{2}{*}{ Mediator variable } & MSW & The natural logarithm of top 3 executive compensation \\
\hline & MSH & The natural logarithm of management's shareholding \\
\hline \multirow{7}{*}{ Control variables } & Size & Total assets' natural logarithm \\
\hline & Lev & Year-end book total liabilities/Year-end book total assets \\
\hline & Grow & Growth rate of main business income \\
\hline & Ocfps & $\begin{array}{l}\text { Net increase in cash and cash equivalents for the period/Total } \\
\text { equity }\end{array}$ \\
\hline & AT & Operating income/Average total assets \\
\hline & Board & Number of Board of Directors \\
\hline & Year & $\begin{array}{c}\text { Control the impact of macroeconomic factors in different } \\
\text { years }\end{array}$ \\
\hline
\end{tabular}

Table 2. Variables design. 


$$
Y=\beta_{0}+\beta_{1} X+\beta_{2} W+\beta_{3} Z+\beta_{4} X Z+\beta_{5} W Z+\beta_{6} \text { Controls }+\varepsilon
$$

Among them, $Y$ is the explained variable corporate performance (ROA), $X$ is the explanatory variable equity $\operatorname{mix}(\mathrm{OMD}), W$ is the mediator variable, which is the executive compensation incentive (MSW) and the executive equity incentive (MSH), and $Z$ is the moderating variable. $Z$ and $X$ are the same variables, $X Z$ is the quadratic term of equity mixing degree, and $\mathrm{WZ}$ is the interaction term of equity mix and executive incentives. Model (2) is used to test the " $U$ "'-shaped relationship between equity mix and executive incentives, and model (3) is used to test the " $U$ "'-shaped effect of equity mix on corporate performance, and test the mediating role played by executive incentives between equity mix and corporate performance and moderating effect of equity mix. To avoid the multicollinearity problem caused by introduction of quadratic terms and interaction terms in the model, this paper centralizes the variables that need to be multiplied.

\section{Empircial Analysis and Results}

\subsection{Descriptive Analysis}

In the empirical analysis stage, we first use Stata 15.0 to perform variables' descriptive analysis.

As shown in Table 3. We found that the maximum value of corporate performance (ROA) is 0.2267 , the minimum value is -0.1460 , and the mean value is 0.0471, indicating that the overall performance level of mixed ownership companies is relatively low. The maximum value of equity mix (OMD) is 0.9514 , the minimum value is 0.0082 and the mean value is 0.2390 , indicating that the equity mix of the sample companies is generally low. The maximum value of executive short-term compensation incentives (MSW) is 16.7669 , the minimum value is 13.1032 , the mean value is 14.6798 , the standard deviation is 0.7200 , and the difference is small, indicating executive compensation incentives are more common in Chinese companies. The maximum value of long-term executive

Table 3. Descriptive analysis of variables.

\begin{tabular}{cccccc}
\hline Variables & Obs & Mean & Std.Dev & Min & Max \\
\hline ROA & 3100 & 0.0471 & 0.0585 & -0.1460 & 0.2267 \\
OMD & 3100 & 0.2056 & 0.2390 & 0.0082 & 0.9514 \\
MSW & 3100 & 14.6798 & 0.7200 & 13.1032 & 16.7669 \\
MSH & 3100 & 14.4935 & 3.8122 & 5.2983 & 20.5532 \\
Size & 3100 & 22.6087 & 1.2288 & 20.1970 & 26.0552 \\
Lev & 3100 & 0.4166 & 0.1873 & 0.0592 & 0.8638 \\
Grow & 3100 & 0.1314 & 0.2764 & -0.4486 & 1.4782 \\
Ocfps & 3100 & 0.1313 & 0.6474 & -1.6946 & 3.0025 \\
AT & 3100 & 0.6516 & 0.3811 & 0.1276 & 2.3910 \\
Board & 3100 & 8.7303 & 1.6603 & 4.0000 & 17.0000 \\
\hline
\end{tabular}


equity incentives (MSH) is 20.5532, the minimum is 5.2983 , and the average is 14.4935 , the standard deviation of equity incentives is 3.8122 , indicating that the implementation of equity incentives varies greatly in different companies.

\subsection{Correlation Analysis}

The results of correlation analysis are shown in Table 4. We found that the degree of equity mix (OMD), executive incentives (MSW and MSH), and corporate performance (ROA) have strong correlations between each other, which are roughly in line with the expected hypothesis. In addition, all the control variables have a strong correlation with company performance, which shows that adding these control variables to the model can better improve the goodness of fit of the model.

\subsection{Empirical Analysis}

As shown in Table 5. The variance inflation factors of all continuous variables in models (1), (2), and (3) range from [1.05, 1.90], which are all far less than 10, indicating that there is no multicollinearity problem.

First, we test the "U"-shaped relationship between equity mix and company performance in Hypothesis 1, and use hierarchical regression to examine the linear relationship between equity mix and corporate performance, and then add the quadratic terms of equity mix to the model to verify the " $U$ "-shaped relationship. From the regression results of models (1a) and (1b), it can be seen that after adding the quadratic term of equity mixing degree, the R-square of model (1b) is significantly improved compared with model (1a), indicating that the goodness of fit of model (1b) is better. The quadratic coefficient of the equity mixing degree is distinctly positive, and the primary coefficient of the equity mixing degree is distinctly negative, indicating that there is a " $U$ "-shaped

Table 4. Correlation analysis.

\begin{tabular}{|c|c|c|c|c|c|c|c|c|c|c|}
\hline & ROA & OMD & MSW & MSH & Size & Lev & Grow & Ocfps & $\mathrm{AT}$ & Board \\
\hline ROA & 1 & & & & & & & & & \\
\hline OMD & $-0.047^{\star * \star}$ & 1 & & & & & & & & \\
\hline MSW & $0.314^{\star * *}$ & $0.102^{\star * *}$ & 1 & & & & & & & \\
\hline MSH & $0.164^{\star * *}$ & $-0.135^{* * *}$ & $0.120^{* * *}$ & 1 & & & & & & \\
\hline Size & $0.056^{\star * *}$ & $0.171^{\star \star \star}$ & $0.464^{\star * *}$ & $-0.108^{\star * *}$ & 1 & & & & & \\
\hline Lev & $-0.363^{\star * *}$ & $0.111^{\star * *}$ & $0.082^{* * *}$ & $-0.217^{\star * *}$ & $0.520^{\star * *}$ & 1 & & & & \\
\hline Grow & $0.287^{* * *}$ & -0.010 & $0.058^{* * *}$ & $0.095^{* * *}$ & $0.047^{* * *}$ & 0 & 1 & & & \\
\hline Ocfps & $0.178^{* * *}$ & 0.011 & $0.093^{* * *}$ & $-0.039^{\star *}$ & $0.139^{* * *}$ & 0.026 & $0.137^{* * *}$ & 1 & & \\
\hline $\mathrm{AT}$ & $0.184^{\star * *}$ & -0.007 & $0.163^{\star * *}$ & $-0.184^{\star * *}$ & $0.134^{* * *}$ & $0.158^{\star * *}$ & $0.099^{* * *}$ & 0.021 & 1 & \\
\hline Board & $-0.034^{\star}$ & $0.197^{\star * *}$ & $0.091^{\star * *}$ & $-0.110^{\star * \star}$ & $0.241^{\star \star *}$ & $0.191^{\star * *}$ & -0.007 & 0.021 & $0.049^{* * *}$ & 1 \\
\hline
\end{tabular}

a. ${ }^{\star * *},{ }^{* *}$, and ${ }^{\star}$ denote two-tailed significance at the $1 \%, 5 \%$, and $10 \%$ levels, respectively. 
Table 5. Empirical analysis.

\begin{tabular}{|c|c|c|c|c|c|c|}
\hline Variable & $\begin{array}{l}(1 \mathrm{a}) \\
\text { ROA }\end{array}$ & $\begin{array}{l}\text { (1b) } \\
\text { ROA }\end{array}$ & $\begin{array}{c}(2 a) \\
\text { MSW }\end{array}$ & $\begin{array}{l}\text { (2b) } \\
\text { MSH }\end{array}$ & $\begin{array}{l}(3 a) \\
\text { ROA }\end{array}$ & $\begin{array}{l}(3 b) \\
\text { ROA }\end{array}$ \\
\hline OMD & $\begin{array}{c}-0.0078^{\star *} \\
(-2.15)\end{array}$ & $\begin{array}{c}-0.0180^{* *} \\
(-2.54)\end{array}$ & $\begin{array}{c}-0.2131^{\star *} \\
(-2.36)\end{array}$ & $\begin{array}{c}-5.6780^{* * *} \\
(-11.14)\end{array}$ & $\begin{array}{c}-0.0139 * * \\
(-2.03)\end{array}$ & $\begin{array}{l}-0.0097 \\
(-1.35)\end{array}$ \\
\hline OMD2 & & $\begin{array}{c}0.0255^{\star} \\
(1.77)\end{array}$ & $\begin{array}{c}0.7984^{* * *} \\
(4.22)\end{array}$ & $\begin{array}{c}9.7620^{* * *} \\
(8.69)\end{array}$ & $\begin{array}{l}0.0096 \\
(0.68)\end{array}$ & $\begin{array}{l}0.0124 \\
(0.86)\end{array}$ \\
\hline $\begin{array}{l}\mathrm{OMD}^{*} \\
\text { MSW }\end{array}$ & & & & & 0.0014 & \\
\hline $\begin{array}{l}\mathrm{OMD}^{*} \\
\mathrm{MSH}\end{array}$ & & & & & & $\begin{array}{l}0.0009 \\
(0.83)\end{array}$ \\
\hline MSW & & & & & $\begin{array}{c}0.0193^{* * *} \\
(14.38)\end{array}$ & \\
\hline MSH & & & & & & $\begin{array}{c}0.0016^{\star * *} \\
(6.18)\end{array}$ \\
\hline Size & $\begin{array}{c}0.0139^{* * *} \\
(15.35)\end{array}$ & $\begin{array}{c}0.0139^{* * *} \\
(15.36)\end{array}$ & $\begin{array}{c}0.3176^{* * *} \\
(26.69)\end{array}$ & $\begin{array}{c}0.1460^{\star *} \\
(2.22)\end{array}$ & $\begin{array}{c}0.0078^{* * *} \\
(7.84)\end{array}$ & $\begin{array}{c}0.0136^{\star * *} \\
(14.96)\end{array}$ \\
\hline Lev & $\begin{array}{c}-0.1704^{\star * *} \\
(-26.65)\end{array}$ & $\begin{array}{c}-0.1698^{* * *} \\
(-26.54)\end{array}$ & $\begin{array}{c}-0.8406^{* * *} \\
(-12.41)\end{array}$ & $\begin{array}{c}-3.6990^{\star * *} \\
(-8.88)\end{array}$ & $\begin{array}{c}-0.1536^{* * *} \\
(-23.64)\end{array}$ & $\begin{array}{c}-0.1643^{* * *} \\
(-25.28)\end{array}$ \\
\hline Grow & $\begin{array}{c}0.0500^{* * *} \\
(12.07)\end{array}$ & $\begin{array}{c}0.0500^{* * *} \\
(12.08)\end{array}$ & $\begin{array}{l}0.0646 \\
(1.49)\end{array}$ & $\begin{array}{c}1.6515^{* * *} \\
(6.39)\end{array}$ & $\begin{array}{c}0.0487^{* * *} \\
(12.33)\end{array}$ & $\begin{array}{c}0.0474^{\star * *} \\
(11.61)\end{array}$ \\
\hline Ocfps & $\begin{array}{c}0.0105^{* * *} \\
(6.97)\end{array}$ & $\begin{array}{c}0.0106^{* * *} \\
(6.99)\end{array}$ & $\begin{array}{l}0.0228 \\
(1.17)\end{array}$ & $\begin{array}{c}-0.2855^{\star * *} \\
(-2.61)\end{array}$ & $\begin{array}{c}0.0101^{* * *} \\
(6.93)\end{array}$ & $\begin{array}{c}0.0110^{\star * *} \\
(7.29)\end{array}$ \\
\hline $\mathrm{AT}$ & $\begin{array}{c}0.0314^{* * *} \\
(11.34)\end{array}$ & $\begin{array}{c}0.0314^{* * *} \\
(11.32)\end{array}$ & $\begin{array}{c}0.2151^{* * *} \\
(6.60)\end{array}$ & $\begin{array}{c}-1.7285^{\star * *} \\
(-10.95)\end{array}$ & $\begin{array}{c}0.0272^{* * *} \\
(10.34)\end{array}$ & $\begin{array}{c}0.0341^{\star * *} \\
(12.24)\end{array}$ \\
\hline Board & $\begin{array}{c}-0.0002 \\
(-0.33)\end{array}$ & $\begin{array}{l}-0.000 \\
(-0.13)\end{array}$ & $\begin{array}{l}-0.0001 \\
(-0.14)\end{array}$ & $\begin{array}{c}-0.0801^{\star *} \\
(-2.17)\end{array}$ & $\begin{array}{l}-0.0001 \\
(-0.11)\end{array}$ & $\begin{array}{l}0.0000 \\
(0.07)\end{array}$ \\
\hline Cons & $\begin{array}{c}-0.2210^{\star * *} \\
(-11.73)\end{array}$ & $\begin{array}{c}-0.2216^{\star * *} \\
(-11.76)\end{array}$ & $\begin{array}{c}7.5805^{* * *} \\
(30.60)\end{array}$ & $\begin{array}{c}15.0237^{\star * *} \\
(11.11)\end{array}$ & $\begin{array}{c}-0.3678^{\star * *} \\
(-17.42)\end{array}$ & $\begin{array}{c}-0.2430^{* * *} \\
(-12.48)\end{array}$ \\
\hline Obs & 3100 & 3100 & 3100 & 3100 & 3100 & 3100 \\
\hline R-squared & 0.3422 & 0.3428 & 0.2894 & 0.1242 & 0.3830 & 0.3517 \\
\hline
\end{tabular}

a. ${ }^{* *},{ }^{* *}$, and ${ }^{*}$ denote two-tailed significance at the $1 \%, 5 \%$, and $10 \%$ levels, respectively.

relationship between the equity mixing degree and corporate performance. That is to say, when the degree of equity mixing is low, it will reduce the corporate performance rather than improve. Only when the equity mixing degree reaches a certain ratio, the equity mixing degree can positively improve the business performance of the enterprises. Hypothesis 1 has been verified. According to the first-order and quadratic coefficients of the equity mixing degree, it can be cal- 
culated that the best advantage of the degree of equity mixing is $35.29 \%$, That is, when the mixed ratio of state-owned shares and non-state-owned shares reaches $35.29 \%$ and above, heterogeneous shareholders can effectively supervise the enterprise, thereby improving corporate performance.

From the regression results of the model $(2 \mathrm{a})$ in Table 5 , we found that the first-order coefficient of equity mixing degree is distinctly negatively correlative with executive compensation incentives, and the quadratic coefficient is significantly negatively correlated with executive compensation incentives. It indicates that the degree of equity mix and executive compensation incentives have a significant "U"-shaped relationship, so Hypothesis 2a has been verified. According to the regression results of model (2b), the first-order coefficient of equity mixing degree is significantly negatively correlated with executive equity incentives, and the quadratic coefficient is positively correlated with executive equity incentives, indicating that there is a significant " $U$ "-shaped relationship between equity mixing degree and executive compensation incentives. Hypothesis $2 \mathrm{~b}$ has been confirmed.

From the results of model (3a), after adding executive compensation incentives to model (1b), the R-square is significantly improved. Although the first-order coefficient of equity mixing and corporate performance is still at the level of $5 \%$ significance, the coefficient has declined, and the coefficient of executive compensation incentives is significantly positive, which shows that executive compensation incentives have a partial mediating effect between the equity mix degree and corporate performance. Therefore, Hypothesis $3 \mathrm{a}$ has been verified. According to the regression results of the model (3b), the R-square of the model ( $3 b$ ) is significantly higher than that of the model (1b), the first-order coefficient of the equity mixing degree becomes insignificant, and the executive equity incentive coefficient is significantly positive. It shows that executive equity incentives have a completely mediating effect between equity mixing degree and firm performance. Hypothesis $3 \mathrm{~b}$ has been confirmed. In addition, the results of models (3a) and (3b) show that the interaction coefficient of equity mixing degree and executive incentives are not significant, which shows that the equity mixing degree has no moderating effect in the process of executive incentives affecting corporate performance.

\subsection{Robustness Test}

To test above regression results' robustness, this paper has done a robustness check. The different degrees of equity nature are mixed, and the company's performance may be improved by increasing the level of executive incentives. There may be a certain lag, and its impact on the corporate performance may be reflected in the next year. Therefore, this paper selects the lagging ROA to measure corporate performance level and conduct a robustness test. The results are represented in Table 6.

From Table 6, we found that the equity mixing degree and business performance 
Table 6. Robustness test.

\begin{tabular}{|c|c|c|c|c|c|c|}
\hline Variable & $\begin{array}{l}\text { (1a) } \\
\text { ROA }\end{array}$ & $\begin{array}{l}(1 b) \\
\text { ROA }\end{array}$ & $\begin{array}{c}(2 a) \\
\text { MSW }\end{array}$ & $\begin{array}{c}\text { (2b) } \\
\text { MSH }\end{array}$ & $\begin{array}{l}(3 a) \\
\text { ROA }\end{array}$ & $\begin{array}{l}(3 b) \\
\text { ROA }\end{array}$ \\
\hline OMD & $\begin{array}{c}-0.0045 \\
(-1.21)\end{array}$ & $\begin{array}{c}-0.0161^{\star *} \\
(-2.27)\end{array}$ & $\begin{array}{c}-0.2194^{\star *} \\
(-2.45)\end{array}$ & $\begin{array}{c}-5.6446^{* * *} \\
(-11.11)\end{array}$ & $\begin{array}{c}-0.0124^{*} \\
(-1.79)\end{array}$ & $\begin{array}{c}-0.0116 \\
(-1.61)\end{array}$ \\
\hline OMD2 & & $\begin{array}{c}0.0290^{* *} \\
(1.97)\end{array}$ & $\begin{array}{c}0.8102^{* * *} \\
(4.29)\end{array}$ & $\begin{array}{c}9.7089^{* * *} \\
(8.65)\end{array}$ & $\begin{array}{l}0.0162 \\
(1.10)\end{array}$ & $\begin{array}{l}0.0240 \\
(1.64)\end{array}$ \\
\hline $\begin{array}{l}\mathrm{OMD}^{*} \\
\text { MSW }\end{array}$ & & & & & $\begin{array}{l}-0.0022 \\
(-0.46)\end{array}$ & \\
\hline $\begin{array}{l}\mathrm{OMD}^{*} \\
\mathrm{MSH}\end{array}$ & & & & & & $\begin{array}{c}0.0021^{\star *} \\
(2.03)\end{array}$ \\
\hline MSW & & & & & $\begin{array}{c}0.0168^{\star * *} \\
(12.03)\end{array}$ & \\
\hline MSH & & & & & & $\begin{array}{c}0.0010^{* * *} \\
(4.03)\end{array}$ \\
\hline Size & $\begin{array}{c}0.0102^{* * *} \\
(10.99)\end{array}$ & $\begin{array}{c}0.0102^{* * *} \\
(11.00)\end{array}$ & $\begin{array}{c}0.3177^{* * *} \\
(26.66)\end{array}$ & $\begin{array}{c}0.1466^{\star *} \\
(2.22)\end{array}$ & $\begin{array}{c}0.0048^{* * *} \\
(4.60)\end{array}$ & $\begin{array}{c}0.0098^{* * *} \\
(10.63)\end{array}$ \\
\hline Lev & $\begin{array}{c}-0.1300^{* * *} \\
(-19.99)\end{array}$ & $\begin{array}{c}-0.1294^{* * *} \\
(-19.92)\end{array}$ & $\begin{array}{c}-0.8395^{* * *} \\
(-12.34)\end{array}$ & $\begin{array}{c}-3.7309^{* * *} \\
(-8.94)\end{array}$ & $\begin{array}{c}-0.1153^{* * *} \\
(-17.20)\end{array}$ & $\begin{array}{c}-0.1261^{* * *} \\
(-19.26)\end{array}$ \\
\hline Grow & $\begin{array}{c}0.0333^{* * *} \\
(8.36)\end{array}$ & $\begin{array}{c}0.0332^{* * *} \\
(8.35)\end{array}$ & $\begin{array}{l}0.0634 \\
(1.46)\end{array}$ & $\begin{array}{c}1.6660^{* * *} \\
(6.43)\end{array}$ & $\begin{array}{c}0.0322^{* * *} \\
(8.32)\end{array}$ & $\begin{array}{c}0.0316^{* * *} \\
(7.93)\end{array}$ \\
\hline Ocfps & $\begin{array}{c}0.0067^{* * *} \\
(4.37)\end{array}$ & $\begin{array}{c}0.0067^{* * *} \\
(4.39)\end{array}$ & $\begin{array}{l}0.0223 \\
(1.14)\end{array}$ & $\begin{array}{c}-0.2882^{* * *} \\
(-2.64)\end{array}$ & $\begin{array}{c}0.0063^{* * *} \\
(4.18)\end{array}$ & $\begin{array}{c}0.0070^{* * *} \\
(4.57)\end{array}$ \\
\hline AT & $\begin{array}{c}0.0283^{* * *} \\
(10.70)\end{array}$ & $\begin{array}{c}0.0282^{* * *} \\
(10.69)\end{array}$ & $\begin{array}{c}0.2135^{* * *} \\
(6.55)\end{array}$ & $\begin{array}{c}-1.7072^{\star * *} \\
(-10.85)\end{array}$ & $\begin{array}{c}0.0246^{* * *} \\
(9.71)\end{array}$ & $\begin{array}{l}0.0302^{\star *} \\
\star(11.31)\end{array}$ \\
\hline Board & $\begin{array}{l}-0.0000 \\
(-0.09)\end{array}$ & $\begin{array}{l}0.0001 \\
(0.13)\end{array}$ & $\begin{array}{l}-0.0001 \\
(-0.02)\end{array}$ & $\begin{array}{c}-0.0749^{*} \\
(-1.95)\end{array}$ & $\begin{array}{l}0.0001 \\
(0.13)\end{array}$ & $\begin{array}{l}0.0005 \\
(0.22)\end{array}$ \\
\hline Cons & $\begin{array}{c}-0.1468^{* * *} \\
(-7.69)\end{array}$ & $\begin{array}{c}-0.1474^{* * *} \\
(-7.73)\end{array}$ & $\begin{array}{c}7.5824^{* * *} \\
(30.60)\end{array}$ & $\begin{array}{c}14.9612^{* * *} \\
(11.05)\end{array}$ & $\begin{array}{c}-0.2757^{\star * *} \\
(-12.93)\end{array}$ & $-0.1580^{* * *}$ \\
\hline Obs & 3090 & 3090 & 3090 & 3090 & 3090 & 3090 \\
\hline R-squared & 0.2239 & 0.2248 & 0.2888 & 0.1240 & 0.2595 & 0.2300 \\
\hline
\end{tabular}

a. ${ }^{* *},{ }^{* *}$, and ${ }^{*}$ denote two-tailed significance at the $1 \%, 5 \%$, and $10 \%$ levels, respectively.

still show a " $U$ "-shaped relationship, and executive incentives still have a mediating effect between the equity mix degree and corporate performance, which is in line with the above results, so the research findings are reliable and robust.

From the above empircial analysis, the research results found that: 1) the degree of equity mix has a distinct " $U$ " relationship with company performance; 2 ) the equity mix has an obvious " $U$ " relationship with executive compensation and 
equity incentives; 3) executives compensation incentives have a partial mediating effect between equity mix and company performance. Executive equity incentives have a complete mediating effect between equity mix and company performance; 4) the equity mix has no moderating effect in the process of executive incentives affecting corporate performance.

\section{Conclusion and Recommendations}

This paper uses the A-share manufacturing public companies in Shanghai and Shenzhen stock exchanges from 2015 to 2019 as research subjects to explore the comprehensive relationship among equity mix, executive incentives and company performance, and verifies the intermediary role of executive incentives in the process of equity mixing degree affecting corporate performance.

The research results found that: 1) the degree of equity mix has a distinct " $U$ " relationship with company performance, only when the equity mixing degree reaches a certain ratio, the equity mixing degree can positively improve the business performance of the enterprises; 2) the equity mix has an obvious " $U$ " relationship with executive compensation and equity incentives, when the degree of mix of state-owned stock and non-state-owned stock reaches a certain ratio, non-state-owned stockholders can take part in the decision-making and achieve the purpose of supervision, so that it can improve the executive compensation incentives and the level of executive shareholding; 3) executives compensation incentives have a partial mediating effect between equity mix and company performance. Executive equity incentives have a complete mediating effect between equity mix and company performance; 4) the equity mix has no moderating effect in the process of executive incentives affecting corporate performance.

Therefore, we make some recommendations as follows:

First, fully consider the degree of equity mix. Throughout the "mixed ownership reform", mixed-ownership enterprises should continuously improve their governance structure to ensure a dynamic balance between state-owned capital and non-state-owned capital. The empirical findings indicate that there is a distinct $\mathrm{U}$-shaped relationship between the equity mixing degree and corporate performance. Therefore, only by introducing non-state capital into the state-owned capital of state-owned companies in the "mixed ownership reform", controlling the degree of equity mix in a reasonable range, and giving full play to supervisory role of non-state shareholders, inspection and checks and balances, can they better facilitate the long-term economic development of the enterprise.

Second, companies should improve the corresponding incentive mechanism according to their own conditions. Both executive compensation incentives and equity incentives are effectively incentive mechanisms that can fully mobilize the enthusiasm of the management to achieve an impact on corporate performance. The empirical results found that in most of the mixed-ownership enterprises, the management shareholding ratio of most enterprises is low, and there is a large 
gap in the shareholding of executives among enterprises, making it difficult for executives to exert their subjective initiative, and the equity incentive mechanism needs to be further improved. The executive incentives policy should be actively implemented, and companies should scientifically and rationally design the senior executive's salary structure, improve the equity incentive mechanism, alleviate the principal-agent problem, reduce corporate agency costs, thereby improving corporate performance.

Third, it is recommended to introduce relevant policies to improve the effectiveness of "mixed-ownership reform". The original intention of mixed-ownership reform is to enhance the competitiveness of state-owned companies by adjusting the state economy structure, and ultimately achieve the improvement of corporate performance. When sorting out the relevant materials of the "mixed ownership reform", this paper found that some "mixed ownership reform" enterprises only completed the change of the shareholding structure, and did not reflect the "reform" in the actual operation and management. After "mixed-ownership reform", non-state-owned stockholders cannot attend major corporate decisions. Therefore, government departments should introduce relevant policies and plans to strengthen the supervision of the "mixed ownership reform" process, thereby promoting the healthy and long-term development of the enterprise.

\section{Conflicts of Interest}

The author declares no conflicts of interest regarding the publication of this paper.

\section{References}

Bennedsen, M., \& Wolfenzon, D. (2000). The Balance of Power in Closely Held Corporations. Journal of Financial Economics, 58, 113-139. https://doi.org/10.1016/S0304-405X(00)00068-4

Cai, G. L., Liu, J. H., \& Ma, X. X. (2018). Governance of Non-State-Owned Shareholders and Remuneration Incentives for Senior Managersin State-Owned Enterprises. Management World, 34, 137-149.

Cheng, Z. M., \& Xia, Y. (2008). Institutional Changes, State Holdings and Equity Incentives. Nankai Management Review, No. 4, 89-96.

Du, Y. Z., Zhang, Y. L., \& Ren, B. (2012). Show or Hide Competitive Advantage: The Mediating Role of the U-Shaped Relationship between the Competitor Orientation and Performance of the New Enterprise and the Legitimacy of the Organization. Management World, No. 7, 96-107.

Hall, B. J., \& Liebman, J. B. (1998). Are CEOs Really Paid Like Bureaucrats. The Quarterly Journal of Economics, 113, 653-691.

Huo, X. P., Li, H. W., \& Qiu, S. (2019). Mixed Ownership, Executive Compensation and Technological Innovation. Friends of Accounting, No. 4, 146-152.

Megginson, W., \& Netter, J. M. (2001). From State to Market: A Survey of Empirical Studies on Privatization. Journal of Economic Literature, 39, 321-389. 
https://doi.org/10.1257/jel.39.2.321

Pagano, M., \& Roell, A. (1998). The Choice of Stock Ownership Structure: Agency Costs, Monitoring, and the Decision to Go Public. Quarterly Journal of Economics, 113, 187-225. https://doi.org/10.1162/003355398555568

Qian, H. G., \& Liu, Y. (2019). The Impact of Mixed Ownership and Ownership Structure on Company Performance. Statistics and Decision, 35, 185-188.

Xi, Y. P. (2012). An Empirical Study of Management Incentives and Company Value. China Security Futures, No. 1, 60.

Yang, Z. Q., Shi, S. P., Shi, B. R., \& Cao, X. Y. (2016). Mixed Ownership, Equity Incentives and Defensive Behavior in Financing Decisions: Evidence Based on Dynamic Trade-off Theory. Financial Research, 42, 108-120.

Yermack, D. (1995). Do Corporations Award CEO Stock Options Effectively? Journal of Financial Economics, 39, 237-269. https://doi.org/10.1016/0304-405X(95)00829-4

Zou, Y., Wang, P., \& Zhang, L. M. (2015). Equity Incentive, Controlling Shareholder and Cost of Equity Capital. Economic management, No. 6, 98-109. 